\title{
Traction Energy Consumption of Electric Locomotives and Electric Multiple Units at Speed Restrictions
}

\author{
Sz. Fischer \\ Széchenyi István University, Department of Transport Infrastructure \\ Egyetem tér 1, 9026 Győr, Hungary \\ Phone: +36 306306924 \\ e-mail: fischersz@sze.hu
}

Abstract: In this article the author reports the measurements made by traction measuring car of Railway Engineering and Metrological Service Centre (REMSC) in the research and development work "Complex investigation of reduction possibilities of additional costs due to speed restrictions on electric traction railway lines". As results it can be stated that $\alpha$ correction parameters in the research and development work made between 2008 and 2010 should be changed because of specifying. These parameters can be used for calculation of additional acceleration energy after speed restriction sites.

Keywords: railway engineering, traction energy consumption, speed restriction, locomotive, EMU

\section{Introduction}

Analysing electric railway haul there is an important aspect to be considered: speed restrictions will substantially increase traction energy consumption as well as journey time $[1,2]$. Speed restrictions are needed because of transport safety due to railway track faults as well as cancelling of these railway track faults' elimination $[3,4,5]$. In case of diesel locomotives and diesel multiple units (DMUs) the additional traction energy consumption is related naturally to diesel oil.

There are some other disadvantages due to railway track faults:

- irregular vehicle movements [6,7],

- $\quad$ higher stresses in the elements of railway super- and substructure $[3,4,8]$,

- much faster deterioration process of the railway track in case of cancelling of railway track faults' elimination [4,9].

The author has to mention there are a lot of technologies to avoid track faults or slow down deterioration process that can reduce traction energy consumption in the aspect of railway track, some of them: 
- superstructure geometry stabilization with geogrids [10], steel sleepers [11], safety cap and ballast bonding technology [12],

- ballastless superstructure and special railway fastening system [13],

- etc.

There are special methods to decrease total traction energy consumption of the trains publicised in the international literatures. For example recuperated energy can be used and stored more efficiently [14], onboard storage batteries can be utilized for hybrid drive systems [15], onboard ultracaps are useful to energy storage [16]. Fully or partially automated Train Control Systems (TCS) and related operation mathematical algorithms are developed to optimize energy consumption of the trains [17]. Less energy consumption can be reached by target speed optimization [18], and it has to be considered that increased speed influences the wasted energy too [19]. In case of determination of train speed and timetable on the tracks, the difficult sections have to be taken into consideration [20]. These methods are suitable for reducing total traction energy of the trains, but they aren't or only partially adequate for taking into account the energy consumption of the locomotives due to acceleration process after discrete speed restriction.

The research team of Széchenyi István University firstly got research work for exact determination of additional traction energy consumption due to speed restrictions $[21,22,23]$, after that the research and development work was related to comparison of additional traction energy consumption costs and costs of elimination of railway track faults caused by speed restrictions [24].

In the author's [25,26], his pensioner colleague's [22,23] and his research team's previous papers and research reports $[21,24]$ there is an adequate calculation method for determining traction energy consumption of electric locomotives and electric multiple units (EMUs). The $\alpha$ correction parameters are formerly calculated from own energy consumption measurements on locomotives and EMUs, but the used $\alpha$ correction parameters are needed to be specified.

The Hungarian Railways ordered another research and development work from Széchenyi István University in 2011, the topic of this research was the complex analysis of reduction possibilities of additional costs due to speed restrictions on electric haul railway lines. In this research work there are measurements made by traction measuring car of REMSC [27] related to three types of electric locomotives and one type of EMU.

This paper reports the results of new measurements and calculations that belong to traction energy consumption of electric locomotives and EMUs.

\section{Necessity and description of measurements made by traction measuring car}

In the previous researches of our team calculations can be done only with own measured data on locomotives and EMUs.

These vehicles are the followings:

- Railjet trains hauled by 1116 Siemens Taurus locomotives [28],

- passenger trains hauled by 1047 and 1116 Siemens Taurus locomotives [29],

- freight trains hauled by 1047 and 1116 Siemens Taurus locomotives [29], 
- 5341 Stadler Flirt EMU [30],

- 5342 Bombardier Talent EMU [31].

In case total traction energy consumption should be calculated for a determined railway line, correct data are needed for another locomotive too. To get these data additional measurements have to be done. The aim of these measurements is to state the fact that more precise $\alpha$ correction parameters can be used in the calculations which are controlled by traction measurement car.

The simple equations are below:

$$
\begin{gathered}
E_{\text {calc }}=0,5 \cdot m \cdot\left(v^{2}-v_{0}^{2}\right) \cdot 3.6 \cdot 10^{6} \\
E=\alpha \cdot E_{\text {calc }}
\end{gathered}
$$

where

$\mathrm{m}$ - total mass of the train (locomotive and cars) in $\mathrm{kg}$ unit,

$\mathrm{v}$ and $\mathrm{v}_{0}-$ values of acceleration speed step in $\mathrm{m} / \mathrm{s}$ unit,

$\mathrm{E}$ - measured electric energy at an acceleration of a locomotive or EMU in kWh unit,

$\alpha$-correction parameter (factor),

$\mathrm{E}_{\text {calc }}-$ calculated electric energy after Eq. 1 in kWh unit.

Because of the fact that measurements were done only for Railjet, passenger and freight trains hauled by Taurus locomotives as well as Flirt and Talent EMUs (values of Table 1), $\alpha$ correction parameters for other vehicles are determined by our specialist mechanical engineer colleagues to be able to assume traction energy consumption, these parameters are the followings:

- passenger train hauled by V63-1 (1163) [32]: $\quad 1.166$,

- freight train hauled by V63-1 (1163) [32]: 1.280 ,

- $\quad$ passenger train hauled by V43 $(1043,1143,1243,1343)[33]: \quad 1.266$,

- freight train hauled by V43 $(1043,1143,1243,1343)[33]: \quad 1.313$,

- passenger train hauled by M41 $(2241,2341)[34]: \quad 1.884$,

- freight train hauled by M41 $(2241,2341)[34]: \quad 2.000$,

- passenger train hauled by M62-0 (2062) [35]: 1.639 ,

- freight train hauled by M62-0 (2062) [35]: 1.927 ,

- 5429 [36] and 6312 [37] EMUs: $\quad 1.570$.

The goal of the measurement series is to determine $\alpha$ parameter related to several locomotives and passenger as well as freight trains more precisely.

REMSC processed the plan for measurements in October, 2011, after that the measurements were done in April, 2012. Fig. 1. shows the measure train. 


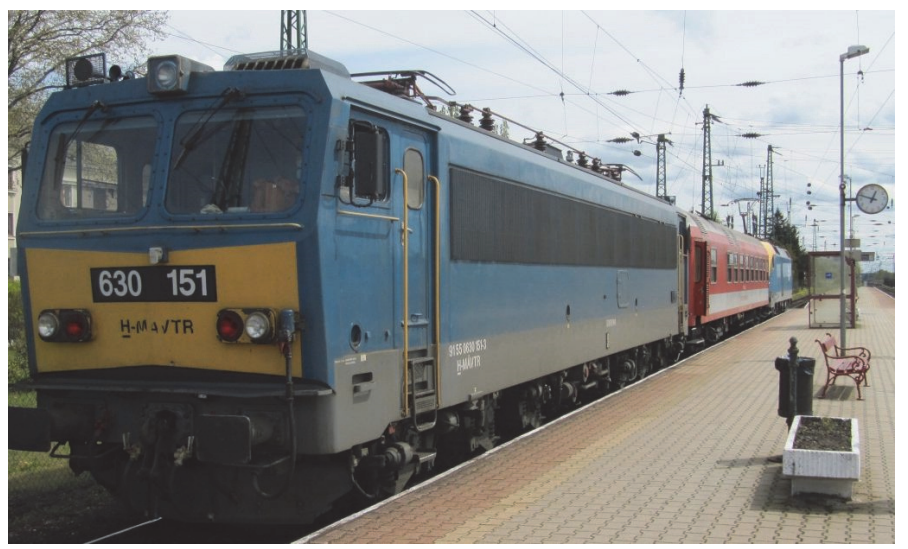

Figure 1. Measure train at Öttevény railway station (Ferenc Horvát's photo)

In Fig. 2. there is the set-up of measure train. At the front there is the analysed haul locomotive, behind that there is the VMK-002 [27] traction measuring car, at the back there is a 1047 Siemens Taurus locomotive that brakes the train.

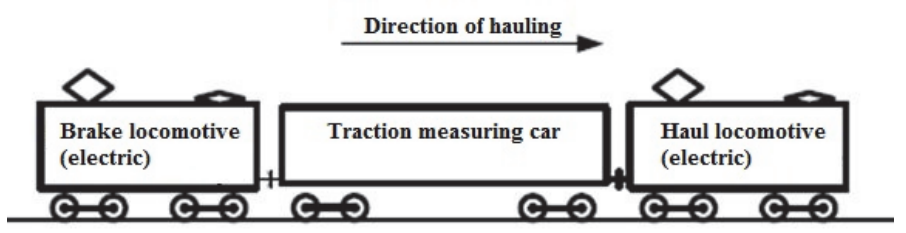

Figure 2. Set-up of measure train

The haul locomotives were the followings in the tests:

- V43 (1338) electric locomotive [33],

- 1047 Siemens Taurus electric locomotive (Taurus) [29],

- V63 (151) electric locomotive [32],

- 5341 (044) Stadler Flirt EMU (Flirt) [30].

Data of the measuring car:

- line number: 6055 99-80 002-2,

- max. speed: $160 \mathrm{~km} / \mathrm{h}$,

- length: $24.5 \mathrm{~m}$,

- weight: $41,000 \mathrm{~kg}$,

- brake mass: $61,000 \mathrm{~kg}$.

Braking simulation was always done with the same 1047 Taurus locomotive. Maximal brake force of this locomotive is $240 \mathrm{kN}$. 
Measure tests were made between railway stations Öttevény and Hegyeshalom on the Hungarian main railway line No. 1. In this section the allowed maximal speed is $160 \mathrm{~km} / \mathrm{h}$. The horizontal geometry is quite straight and the vertical geometry does not contain high slopes only quite horizontal sections, as well as the geometrical condition of the track was good, in this way there isn't any distortional effect to energy consumption results.

The final measure program was as below:

- 16th and 17th of April in 2012: measurements with V43 (1338) locomotive, 40-60-80-100-120 km/h constant speed, as well as several speed steps between 40 and $120 \mathrm{~km} / \mathrm{h}$,

- 18 th and 19th of April in 2012: measurements with Taurus (1047) locomotive, 40-60-80-100-120-140-160 km/h constant speed, as well as several speed steps between 40 and $160 \mathrm{~km} / \mathrm{h}$,

- 23rd and 24th of April in 2012: measurements with V63 (151) locomotive, 40$60-80-100-120 \mathrm{~km} / \mathrm{h}$ constant speed, as well as several speed steps between 40 and $120 \mathrm{~km} / \mathrm{h}$,

- 25th and 26th of April in 2012: measurements with Stadler Flirt EMU (5341) locomotive, 40-60-80-100-120-140-160 km/h constant speed, as well as several speed steps between 40 and $160 \mathrm{~km} / \mathrm{h}$.

The measurements were made only on the right track in case of V43 and V63 locomotives in the right direction (from Öttevény to Hegyeshalom), but measurements related to Taurus locomotive and Stadler Flirt EMU were made on both tracks always in the right direction.

The REMSC calculated the required traction force values for all the locomotives and EMU for constant speed traction as well as the several speed steps. The required power for traction was determined from the traction force vs. speed diagrams for each measurement cases. Speed restrictions were also simulated (braking, traction with constant speed, acceleration), and electric energy consumption was measured during it. Measurements were done by three several brake forces.

From these data the additional energy consumption could be calculated.

Parameters below were recorded during measurements:

- $\mathrm{V}$ - speed in $\mathrm{km} / \mathrm{h}$ unit,

- $\quad \mathrm{s}$ - covered distance in $\mathrm{m}$ unit,

- $\mathrm{U}_{\mathrm{p}}$ - primer voltage in $\mathrm{kV}$ unit,

- $\mathrm{I}_{\mathrm{p}}$ - primer amperage in A unit,

- $\cos \phi$ - phase shift,

- $\mathrm{P}$ - electric power in $\mathrm{kW}$ unit,

- $\quad \mathrm{E}$ - energy consumption in $\mathrm{kWh}$ unit as the integral of $\mathrm{P}(\mathrm{t})$ function,

- $\mathrm{F}_{\mathrm{v}}$ - traction force measured on drawbar in $\mathrm{kN}$ unit, as well as

- combinated speed and distance signal and the section markers.

In the Fig. 3. several parameters are shown on the display of VMK-002 traction measuring car.

All the measured data can't be published because of limited space of this paper. 


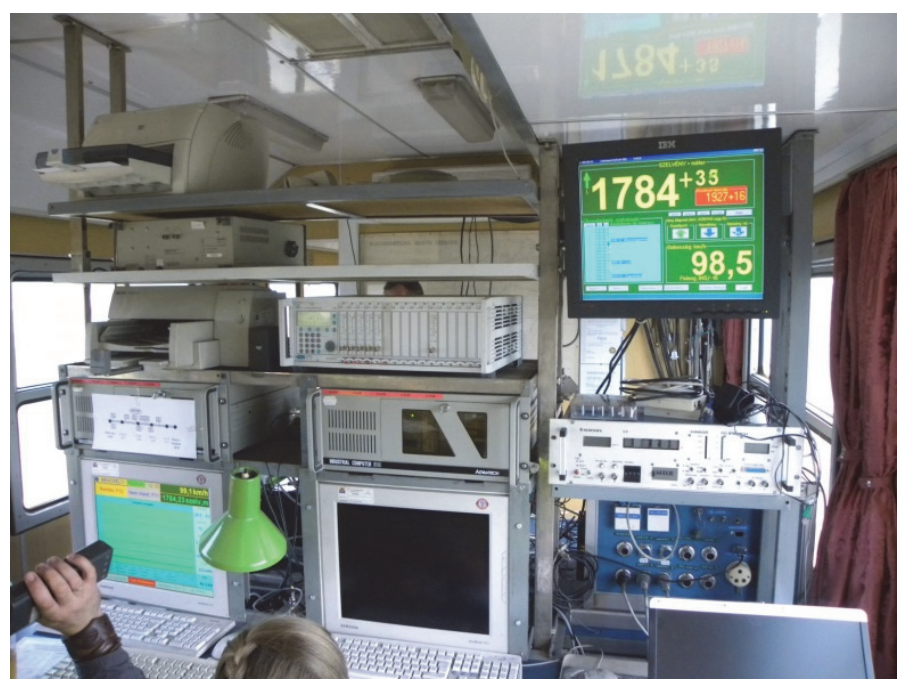

Figure 3. Several parameters on the display of VMK-002 traction measuring car

\section{Data processing and results of measurements}

Measured data from REMSC were processed by calculated specific values, after that specific traction energy data (in $\mathrm{kWh} / 100 \mathrm{~m} / \mathrm{kN}$ unit) were calculated for each locomotives and EMU. The set brake force values were between 10 and $150 \mathrm{kN}(50 \mathrm{kN}$ force simulates passenger train, $100 \mathrm{kN}$ light freight train, and $150 \mathrm{kN}$ heavy freight train). Additional braking wasn't used in case of Stadler Flirt.

During calculation it was supposed that total consumed electric energy was used for transmission of the trains. In case of traction with constant speed the energy equals to the total resistance of the train:

$$
E_{\text {used }}=Q_{\text {total }} \cdot \mu_{\text {train }} \cdot s
$$

where

$\mathrm{E}_{\text {used }}$ - consumed electric energy during the travel in $\mathrm{kWh}$ unit,

$\mathrm{Q}_{\text {total }}$ - total weight of the train consideration with brake force in $\mathrm{kN}$ unit,

$\mu_{\text {train }}$ - resistance of the train in $\mathrm{N} / \mathrm{kN}$ unit,

$\mathrm{s}$ - distance that was taken with constant speed in $\mathrm{m}$ unit.

The calculation of $\mu_{\text {train }}$ is presented below in accordance with Hungarian Railways' recommendation from year 1983 [38]:

- in case of passenger train: 


$$
\mu_{\text {train }}=2+0.047 \cdot \frac{V^{2}}{100}
$$

- in case of freight train:

$$
\mu_{\text {train }}=2+0.057 \cdot \frac{V^{2}}{100}
$$

where

$\mathrm{V}$ - speed of the train in $\mathrm{km} / \mathrm{h}$ unit.

The calculated weight of the train from data of measurements with constant speed is below:

$$
Q_{\text {total }}=3.6 \cdot 10^{5} \cdot \frac{E_{\text {used }}}{\mu_{\text {train }} \cdot S}
$$

The consumed electric energy equals to the sum of energy against resistance of train and acceleration energy in case of assumed uniform acceleration. The calculated train weight in tons unit is as below [39]:

$$
Q_{\text {total }}=3.6 \cdot 10^{5} \cdot \frac{E_{\text {used }}}{\mu_{\text {train }, a v .} \cdot s}+110 \cdot a_{a v} .
$$

where

$\mu_{\text {train,av. }}-$ average of the resistance of the train related to speed values $\mathrm{v}_{1}$ and $\mathrm{v}_{2}$ in $\mathrm{N} / \mathrm{kN}$ unit,

$$
a_{a v}-\text { average acceleration in } \mathrm{m} / \mathrm{s}^{2} \text { unit. }
$$

Fig. 4. - Fig. 6. show the calculated train weights as a function of set brake forces. The $R_{2}$ values in some cases are between 0.5 and 0.75 (weak correlation), but in most cases are between 0.75 and 1.0 (strong correlation). 
Sz. Fischer-Acta Technica Jaurinensis, Vol. 8, No. 3, pp. 240-256, 2015

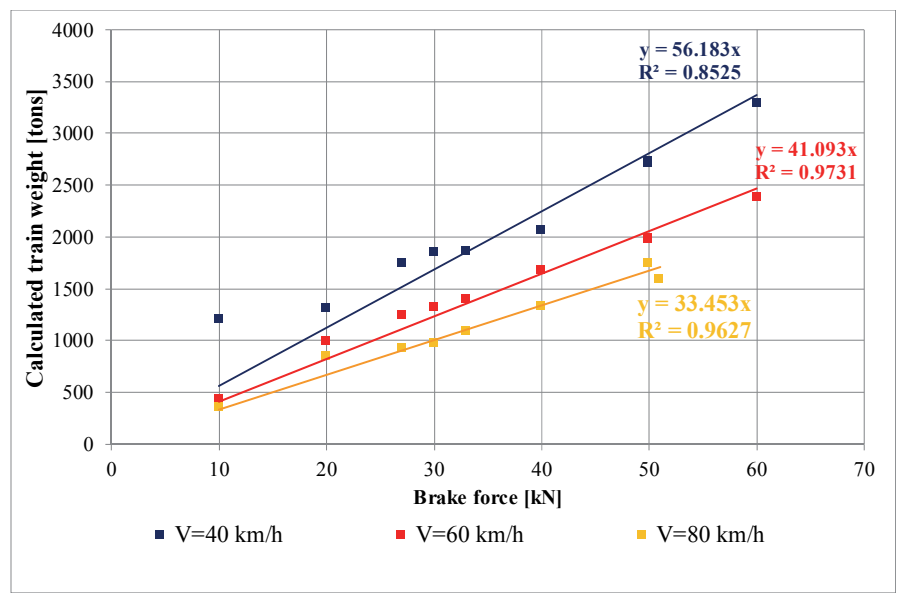

Figure 4. Calculated train weight in case of set several brake forces (V43)

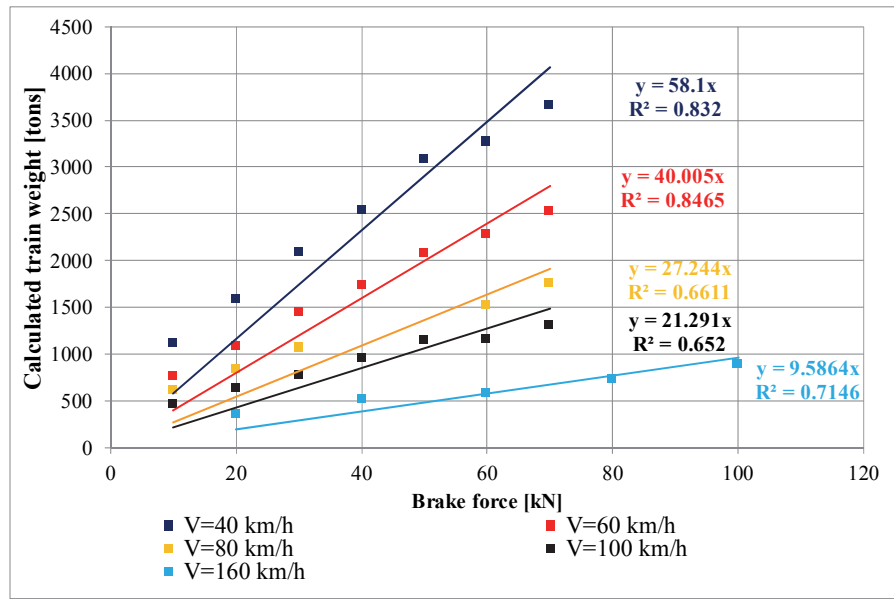

Figure 5. Calculated train weight in case of set several brake forces (Taurus) 


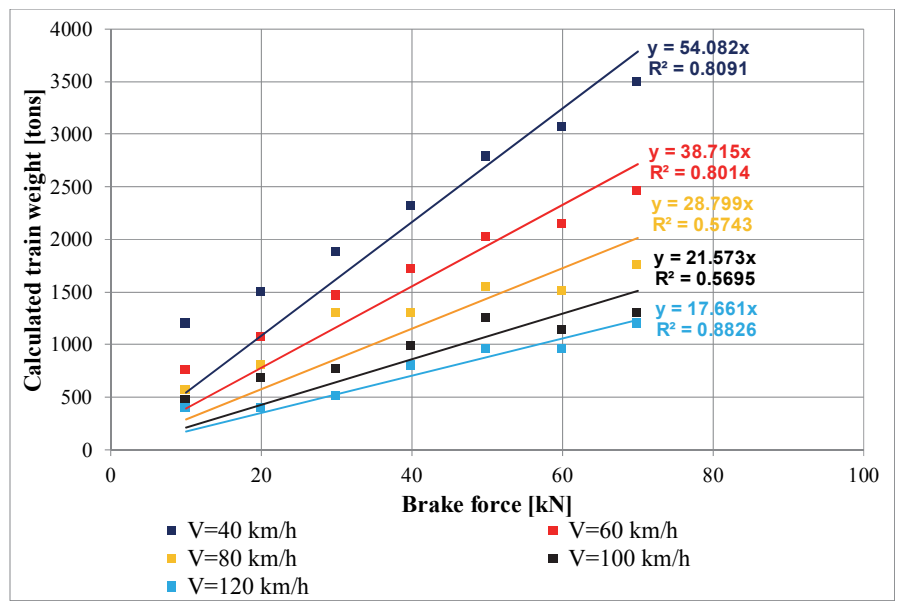

Figure 6. Calculated train weight in case of set several brake forces (V63)

Specific traction energies as a function of train speed are presented in Fig. 7 - Fig. 10. In case of measurements with V43 locomotives the maximum brake force values were $60 \mathrm{kN}$, in this way freight train diagrams couldn't be made.

Relationship was searched between used and calculated energies (Eq. 1 and Eq. 2).

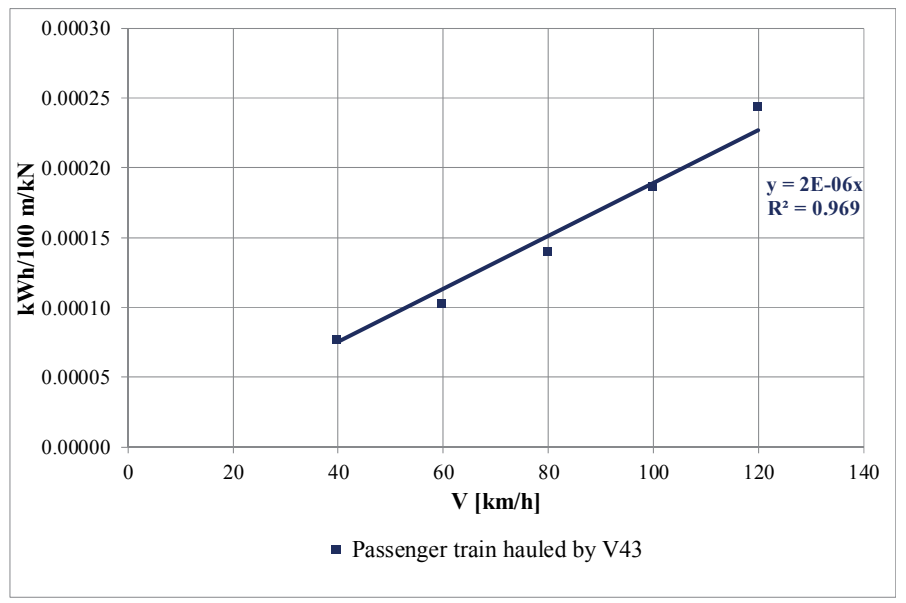

Figure 7. Specified energy consumption of V43 locomotive 
Sz. Fischer-Acta Technica Jaurinensis, Vol. 8, No. 3, pp. 240-256, 2015

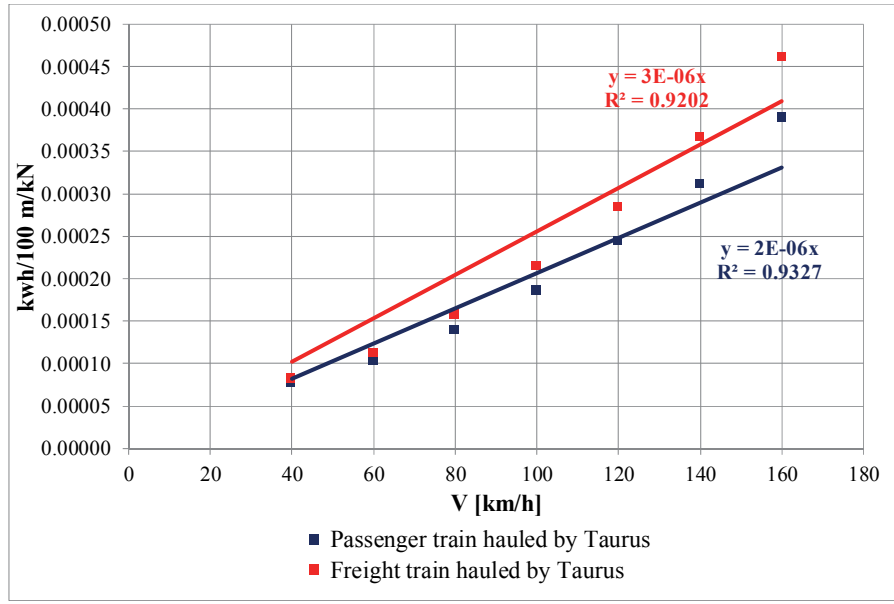

Figure 8. Specified energy consumption of Taurus locomotive

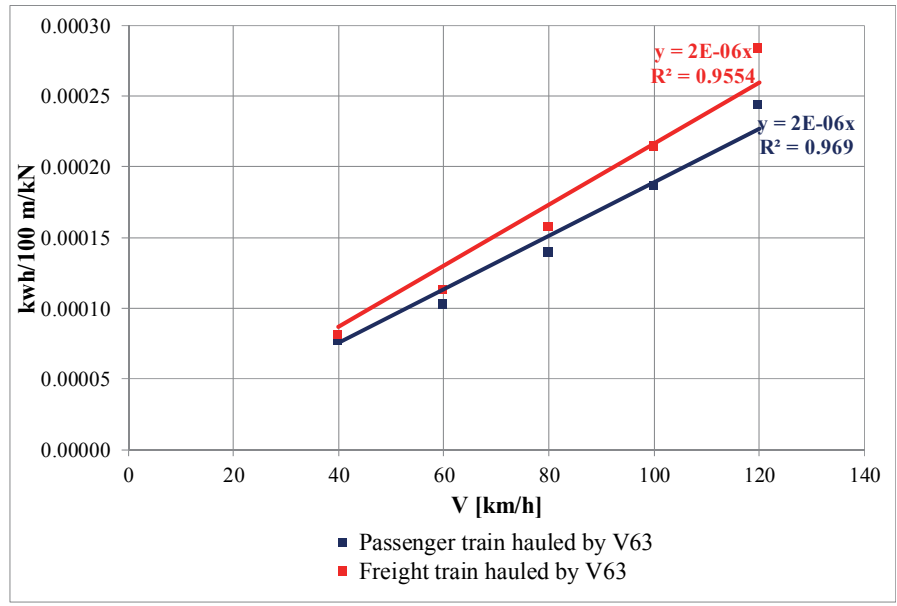

Figure 9. Specified energy consumption of V63 locomotive 


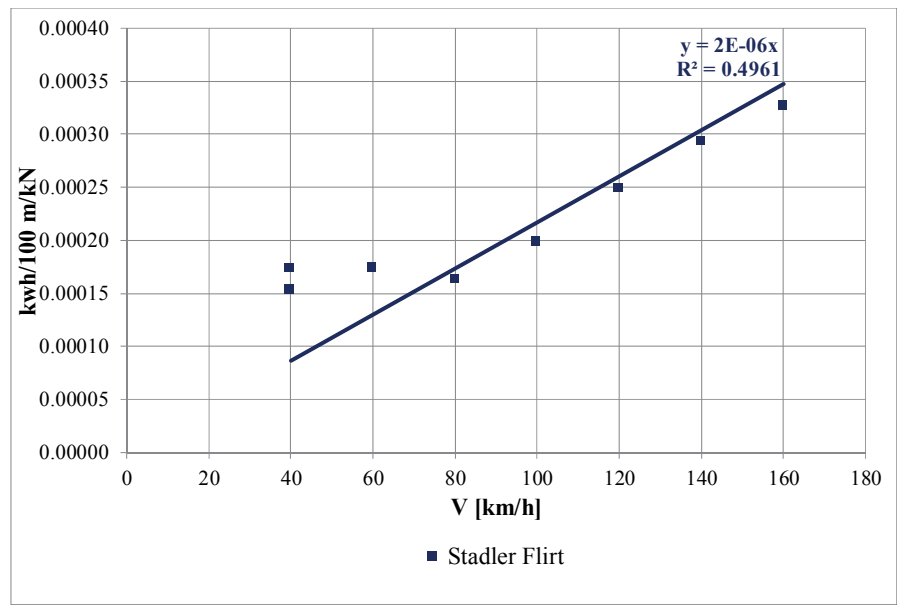

Figure 10. Specified energy consumption of Stadler Flirt EMU

Fig. 11. - Fig. 14. show the electric energy measured by REMSC as a function of calculated energy.

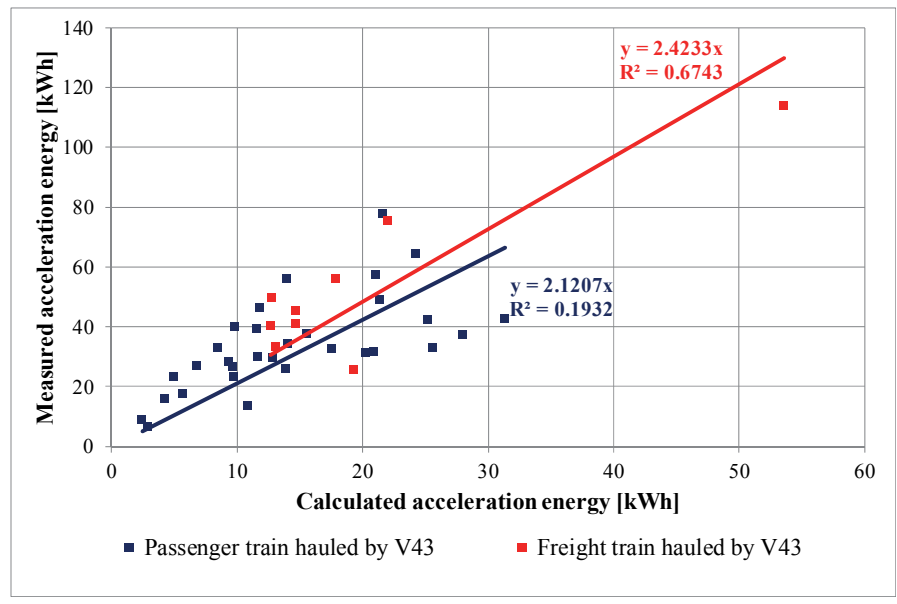

Figure 11. Electric energy measured by REMSC as a function of calculated energy (passenger and freight trains hauled by V43 locomotives) 


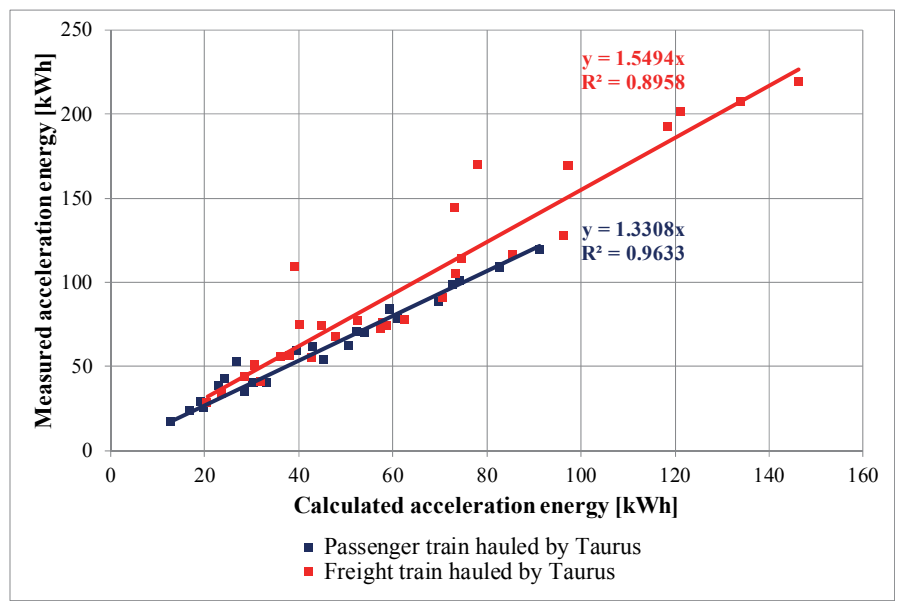

Figure 12. Electric energy measured by REMSC as a function of calculated energy (passenger and freight trains hauled by Taurus locomotives)

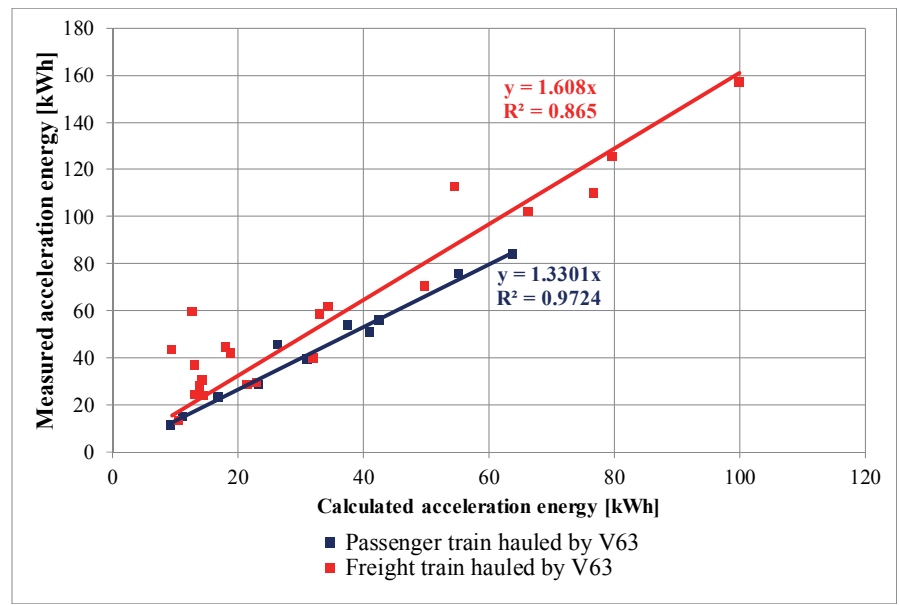

Figure 13. Electric energy measured by REMSC as a function of calculated energy (passenger and freight trains hauled by V63 locomotives) 


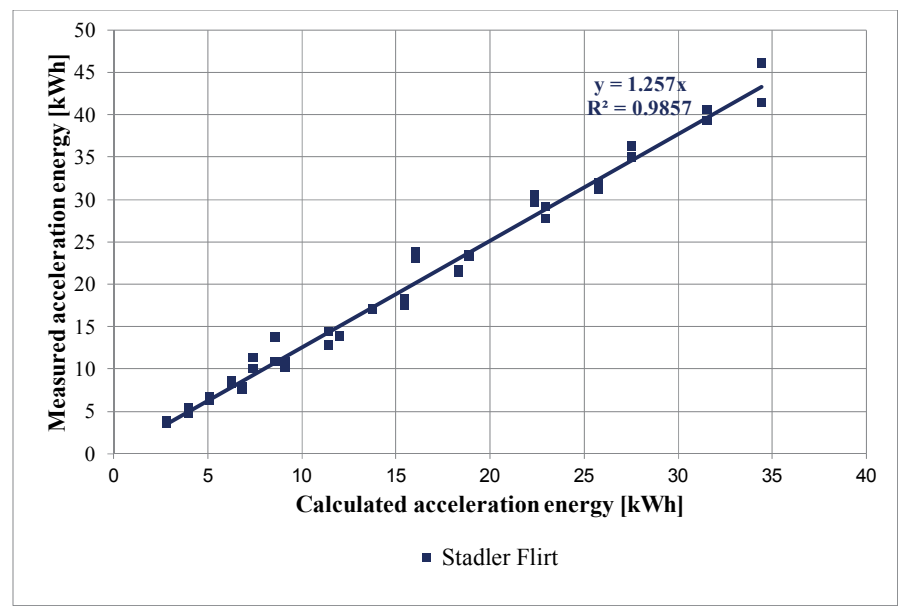

Figure 14. Electric energy measured by REMSC as a function of calculated energy (Stadler Flirt EMU)

Fig. 15. presents the relationship between measured and calculated recuperated energy.

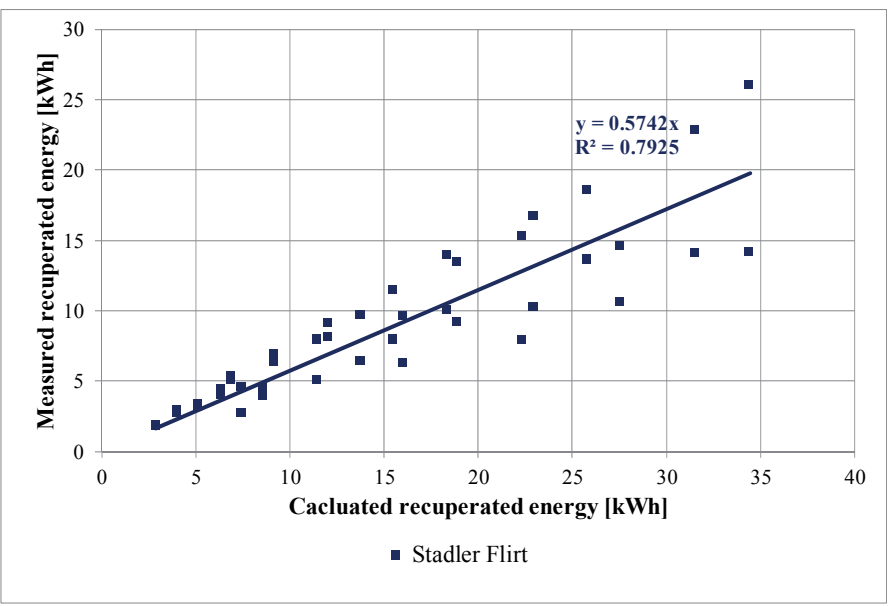

Figure 15. Relationship between measured and calculated recuperated energy (Stadler Flirt EMU)

Comparison of the values measured by REMSC and earlier by our research team is presented in Table 1. 
Table 1. Variance of $\alpha$ correction parameters

\begin{tabular}{|c|c|c|c|c|}
\hline \multirow[b]{2}{*}{ Type of train } & \multicolumn{2}{|r|}{$\alpha$} & \multirow[b]{2}{*}{$\Delta \alpha$} & \multirow{2}{*}{$\begin{array}{c}\text { Deviation from } \\
\text { the values from } \\
\text { REMSC } \\
\text { measurements } \\
\text { (\%) }\end{array}$} \\
\hline & $\begin{array}{c}\text { From } \\
\text { measure- } \\
\text { ments by } \\
\text { REMSC }\end{array}$ & $\begin{array}{c}\text { From earlier } \\
\text { studies and } \\
\text { papers }[24,25,26]\end{array}$ & & \\
\hline P. train - Taurus locomotive & 1.331 & 1.415 & 0.084 & 6.3 \\
\hline F. train-Taurus locomotive & 1.549 & 1.495 & 0.054 & -3.5 \\
\hline RJ train - Taurus locomotive & - & 1.316 & - & - \\
\hline Stadler Flirt EMU & 1.257 & 1.128 & 0.129 & -10.3 \\
\hline Bombardier Talent EMU & - & 1.095 & - & - \\
\hline P. train-V43 locomotive & 2.121 & 1.266 & 0.855 & -40.3 \\
\hline F. train - V43 locomotive & 2.423 & 1.313 & 1.110 & -45.8 \\
\hline P. train-V63 locomotive & 1.330 & 1.166 & 0.164 & 12.3 \\
\hline F. train - V63 locomotive & 1.608 & 1.280 & 0.328 & 20.4 \\
\hline
\end{tabular}

Note: P. train means passenger train, F. train means freight train, RJ means Railjet

\section{Evaluation of the data measured by traction measuring car}

There isn't significant difference between the theoretical calculated and measured (by REMSC) value of $\alpha$ parameter in case of Taurus locomotive and Stadler Flirt EMU, but there is significant deviation in case of V43 and V63 locomotives. This fact should be answered. The theoretical values were determined in the years 2008 and 2009. That time measurements couldn't be done by these locomotives, correction parameters were calculated assuming new locomotives use special data and diagrams. REMSC made measurements by the V0431 338 locomotive in 2012 which vehicle is older than 30 years. Because of this fact a lot of influencing parameters should be considered:

- the efficiency of traction of V43 locomotive is not the best due to the out of date silicon rectifier,

- the main parts and other accessories aren't the original ones in the locomotives.

Main parts and accessories of V0431 338 locomotive used during the measurements have different lifetime and efficiency, they are in different condition too. $1 \%$ decrease of efficiency of main parts with causes about $3 \ldots .5 \%$ decrease of whole efficiency of the vehicle.

The first V63 locomotives are ca. 18..20 years younger than V43s. Maintenance strategy is similar to V43's. Because of this fact significant decrease of efficiency can be assumed. This can explain the experienced difference between theoretical and practical values.

Determined correction parameters derived from measurements of REMSC should be used in the future. Parameters from earlier studies are needed to use only in case of Railjet trains and Bombardier Talent EMUs. Because of the fact that there isn't significant difference between correction parameters in Table 1 related to Taurus locomotive, it can be assumed that correction parameter related to Railjet hauled by Taurus is approximately equals to 1.316. This statement may be true in case of Bombardier Talent EMUs. 


\section{Summary}

This paper summarizes the results and evaluation of measurements done by REMSC's traction measuring car related to R\&D work financed by Hungarian Railways [40]. Publicised $\alpha$ correction parameters determined in earlier studies could be refined. These more accurate values should be used in case of calculation of additional traction energy consumption due to speed restriction [41].

\section{Acknowledgements}

The author and the whole research team thank Dénes Szekeres (MÁV Ltd.), Zsolt Csonka (MÁV Ltd.), Attila Vitéz (MÁV Ltd.), Miklós Simányi (SIU) and the colleagues of MÁV-Trakció Ltd., MÁV-Start Ltd. and REMSC for their help.

\section{References}

[1] Kurhan MB, Mukhina NA, Chernyshova OS: The establishment of a rational sequence of the speed restrictions elimination caused by the railway status.

Science and Transport Progress. Bulletin of Dnipropetrovsk National University of Railway Transport, No. 25, pp. 72-75, 2008.

[2] Kurhan MB, Muhina NA, Chernyshova OS: The forecasting effort changes in traction energy of metrics at any speed. Science and Transport Progress. Bulletin of Dnipropetrovsk National University of Railway Transport, No. 27, pp. 121-124, 2009.

[3] Lichtberger B: Track compendium. Eurailpress Tetzlaff-Hestra GmbH \& Co. KG, Hamburg, 634 p, 2005.

[4] Esveld C: Modern railway track, MRT-Production. Zaltbommel, 723 p, 2001.

[5] Kurhan MB, Zaiats MA: Efficiency determination of freight and passenger traffic division according to the expenses criteria for superstructure maintenance and repair. Science and Transport Progress. Bulletin of Dnipropetrovsk National University of Railway Transport, No. 35, pp. 99-105, 2010.

[6] Iwnicki S (ed.): Handbook of railway vehicle dynamics. CRC Taylor \& Francis Group, Boca Raton, 535 p, 2006.

[7] Knothe K (ed.), Grassie St.L (ed.), Elkins JA (ed.): Interaction of railway vehicles with the track and its substructure. CRC Taylor \& Francis Group, New York, 390 p, 2007.

[8] Kurhan DM: Features of perception of loading elements of the railway track at high speeds of the movement. Science and Transport Progress, Bulletin of Dnipropetrovsk National University of Railway Transport, No. 2, pp. 136-145, 2015.

[9] Robinson M (ed.), Kapoor A (ed.): Fatigue in railway infrastructure. CRC Woodhead Publishing Limited, Padstow, Cornwall, 114 p, 2009.

[10] Horvát F, Fischer Sz, Major Z: Evaluation of railway track geometry stabilisation effect of geogrid layers under ballast on the basis of laboratory multi-level shear box tests. Acta Technica Jauriensis, Vol. 6, No. 2, pp. 21-44, 2013.

[11] Liegner N: Investigation of the internal forces of the first track constructed with Yshape steel sleepers under operation in Hungary. Periodica Polytechnica: Civil Engineering, No. 1-2, pp. 115-130, 2004. 
[12] Szabó J: Tests experiences in small radius curves of continuously welded rail tracks. Periodica Polytechnica: Civil Engineering, No. 2, pp. 177-189, 2011. DOI: $10.3311 /$ pp.ci.2011-2.10

[13] Major Z: Longitudinal Behaviour of Embedded Rails. Acta Technica Jauriensis, Vol. 8, No. 2, pp. 179-187. 2015.

DOI: 10.14513 /actatechjaur.v8.n2.367

[14] Kondo K: Recent Energy Saving Technologies on Railway Traction Systems. IEEJ Transactions on Electrical and Electronic Engineering, No. 5, pp. 298-303, 2010. DOI: $10.1002 /$ tee. 20533

[15] Shimada M, Miyaji Y, Kaneko T, Suzuki K: Energy-saving Technology for Railway Traction Systems Using Onboard Storage Batteries. Hitachi Review, No. 7, pp. 312-318, 2012.

[16] Steiner M, Klohr M, Pagiela S: Energy storage system with ultracaps on board of railway vehicles. Power Electronics and Applications, 2007 European Conference on, Aalborg, 2-5 Sept. pp. 1-10, 2007.

DOI: $10.1109 /$ EPE.2007.4417400

[17] Liu R, Golovitcher IM: Energy-efficient operation of rail vehicles. Transportation Research Part A: Policy and Practice, No. 10, pp. 917-932, 2003.

DOI: $\underline{10.1016 / j . t r a .2003 .07 .001}$

[18] Feng X: Optimization of target speeds of high-speed railway trains for traction energy saving and transport efficiency improvement. Energy Policy, No. 12, pp. 7658-7665, 2011.

DOI: $10.1016 /$ j.enpol.2011.08.051

[19] Korzhenevych IP, Kurgan MB, Barash YuS, Kurhan DM: The impact of the increased speed of trains on wasted energy. Science and Transport Progress. Bulletin of Dnipropetrovsk National University of Railway Transport, No. 20, pp. 233-239, 2008.

[20] Kurhan MB, Kurhan DM, Khmelevska NP, Baidak S.YU: Methodology of determination of admissible speeds of train movement on difficult sections of railroad plan. Science and Transport Progress. Bulletin of Dnipropetrovsk National University of Railway Transport, No. 2, pp. 83-94, 2014.

[21] Universitas-Győr Nonprofit Kft.: A vasúti pályán a lassújelek után szükséges gyorsítások energiaigényének vizsgálata. Research report, Győr, 152 p, 2009.

[22] Kiss F: A vasúti pálya lassújelei okozta vontatási többletenergiák és költségeik. XIII. Nemzetközi Építéstudományi Konferencia, Csíksomlyó, Romania, June 11-14, pp. 237-245, 2009.

[23] Kiss F: A vasúti pálya lassújelei okozta vontatási többletenergiák és költségeik, Közlekedésépítési Szemle, No. 6, pp. 10-16, 2009.

[24] Universitas-Győr Nonprofit Kft.: Lassújelek okozta vontatási energiatöbblet költségeinek és a lassújelet okozó pályahiba kijavítási költségeinek összevetése. Research report, Győr, 199 p, 2010.

[25] Fischer Sz: Lassújel miatti többletköltségek és a megszüntetés költségeinek összehasonlítása. Sínek Világa, No. 5, 2011, pp. 21-29, 2011.

[26] Fischer Sz: A vasúti zúzottkő ágyazat alá beépített georácsok vágánygeometriát stabilizáló hatásának vizsgálata. $\mathrm{PhD}$ thesis, Széchenyi István University Faculty of Engineering Sciences, 148 p, 2012.

[27] http://www.mavintezet.hu/vmmszk/JVO ref en.htm (downloaded: 28.05.2015) 
[28] http://www.tensi.hu/userfiles/files/Angol\%20oldal/Vonat/Railjet.pdf (downloaded: 28.05.2015)

[29] http://www.mobility.siemens.com/mobility/global/sitecollectiondocuments/en/railsolutions/locomotives/reference-list-en.pdf (downloaded: 28.05.2015)

[30] http://www.stadlerrail.com/en/vehicles/flirt/ (downloaded: 28.05.2015)

[31] http://www.bombardier.com/en/transportation/products-services/mainlinesolutions.html (downloaded: 28.05.2015)

[32] http://en.wikipedia.org/wiki/M\%C3\%81V Class V63 (downloaded: 28.05.2015)

[33] http://en.wikipedia.org/wiki/M\%C3\%81V Class V43 (downloaded: 28.05.2015)

[34] http://erojr.home.cern.ch/erojr/Content/models/m41/M41 his.htm (downloaded: 28.05.2015)

[35] http://en.wikipedia.org/wiki/M62 locomotive (downloaded: 28.05.2015)

[36] http://hu.wikipedia.org/wiki/Bzmot (downloaded: 28.05.2015)

[37] http://hu.wikipedia.org/wiki/M\%C3\%81V_6312_sorozat (downloaded: 28.05.2015)

[38] MÁV: Országos Közforgalmú Vasutak Pályatervezési Szabályzata. KÖZDOK, Budapest, 185 p, 1983.

[39] Gajári J: Vasútépítéstan I. Tankönyvkiadó, Budapest, 434 p, 1983.

[40] Széchenyi István Egyetem: Villamos vontatással üzemeltetett vasúti pályákon a sebességkorlátozások okozta többletköltségek csökkentési lehetöségeinek komplex vizsgálata. Research report, Györ, 97 p, 2012.

[41] Fischer Sz: Villamos vontatójármüvek és motorvonatok vontatási energiafogyasztása, Sínek Világa, No. 1, pp. 13-18, 2013. 